\title{
O início, os fins e o meio: o Código Florestal
}

\section{Paulo Velten ${ }^{1}$ \\ Guilherme José Purvin de Figueiredo²}

\section{Resumo}

A edição do Código Florestal de 2012, objeto de inúmeras ações de inconstitucionalidade, representou mais um episódio do retrocesso legislativo na proteção do meio ambiente no Brasil. A decisão pela constitucionalidade de praticamente todos os seus dispositivos legais pelo Supremo Tribunal Federal produziu forte decepção em todos aqueles que se preocupam com a proteção da biodiversidade no país. O presente artigo revisita, sob a forma de revisão bibliográfica, o desenvolvimento das ideias que legitimam a dominação, a exploração e a simplificação da biodiversidade, a partir do contexto histórico-político brasileiro, presentes desde a edição do Código Florestal de 1965 e mantidas no novo Diploma de 2012.

Palavras-chave: Novo Código Florestal. Inconstitucionalidade. Supremo Tribunal Federal. Modus operandi ditatorial. Retrocesso.

\section{Introdução}

As discussões em torno das inconstitucionalidades do Novo Código Florestal ${ }^{3}$ demonstraram, principalmente em função da quase ausência de divergências efetivamente relevantes que dissessem respeito aos efeitos concretos da proteção da biodiversidade, o grau de (des)importância que a temática ecológica tem para os ministros do Supremo Tribunal Federal (STF). A singeleza com a qual as teses jurídicas, apontando retrocessos evidentes foram debeladas, evidencia que a Corte

\footnotetext{
${ }^{1}$ Advogado, Doutor em Direito pela Universidade Estácio de Sá - UNESA, Professor da Universidade Federal do Espirito Santo com experiência nas áreas de Direitos Humanos e Direito Ambiental. Coordeandor da Especialização em Educação em Direitos Humanos na modalidade à distância. Universidade Federal do Espirito Santo - UFES, Espírito Santo - Brasil. E-mail: velten.paulo@gmail.com

${ }^{2}$ Dutor em Direito pela Universidade de São Paulo - USP, Procurador do Estado de São Paulo e Presidente da Aprodab - Associação dos professores de direito ambiental do Brasil. Escola Paulista da Magistratura - São Paulo - Brasil. E-mail: gpurvin@gmail.com

${ }^{3}$ Lei $n^{\circ}$. 12.651/2012.
} 
Suprema parece não estar convencida da relevância, do disposto no capítulo da Constituição de 1988 que foi reservado ao meio ambiente (art. 225).

Considerando que os tópicos em referido julgamento deverão acarretar consequências extremamente graves para a vida das futuras gerações, por se tratar de um conflito intergeracional, mereceria, no mínimo, um debate cientificamente mais qualificado e juridicamente menos contraditório, já que em todos os votos foram feitas afirmações enfáticas de sério compromisso com o respeito aos princípios norteadores do Direito Ambiental.

É evidente o legado de retrocesso legislativo ambiental ${ }^{4}$ que a presente geração está produzindo em terras brasileiras. Quando se leva em consideração que a atual geração foi educada sob os auspícios de uma conscientização ambiental, notadamente após a Constituição de 1988, é paradoxal notar a dificuldade de adesão às teses de proteção ambiental. De igual sorte, forçoso reconhecer a profusão de normas que se contrapõem aos direitos da natureza.

Este artigo pretende analisar esse fenômeno e questionar como, apesar dos inúmeros apelos de preservação florestal mundo afora, o Brasil produziu nos últimos anos uma legislação absolutamente nefasta, anistiando crimes ambientais e facilitando a ampliação do desmatamento, sem que se visse nessa conduta legislativa qualquer forma de violação a preceitos éticos humanitários.

A validação do Código de 2012 gerará conflitos com as próximas gerações e, assim, é possível que estas se ressintam da mentalidade dos legisladores ${ }^{5}$ e juristas do presente tempo.

O distanciamento entre a consciência ambiental, que deveria, em tese, haver adquirido a atual geração, e a prática é consequência, em parte, do "modus operandi ditatorial" já objeto de discussão ${ }^{6}$ que fundamentou as políticas públicas adotadas no Brasil, no que diz respeito à proteção

\footnotetext{
${ }^{4}$ Para citar exemplos de retrocesso legislativo: PL n ${ }^{0}$ 6.299/2002 (pacote do veneno) que flexibiliza ainda mais o uso de agrotóxicos no país, que já é o maior consumidor do mundo desse produto, ou, ainda, os Decretos $\mathrm{n}^{\circ}$ 9.309, $\mathrm{n}^{\circ} 9.310$ e $\mathrm{n}^{\circ}$ 9.311, que regulamentaram a Lei $\mathrm{n}^{\circ} .13 .465 / 2017$, que abre portas para a regularização fundiária de terras griladas e joga pá de cal sobre a política de reforma agrária. Também podemos citar o PL $\mathrm{n}^{\circ}$ 7.488/2017, que impõe restrições a demarcações de terras indígenas, abre espaço para que o empreendedor questione ações de compensação ambiental e libera estados e municípios para criar as próprias regras de licenciamento.

${ }^{5}$ Cite-se como exemplo a reportagem da revista Isto É, que demonstra a pretensão do deputado Jair Bolsonaro defendendo o fim das demarcações de terras indígenas e quilombolas em clara violação de direitos humanos.

${ }^{6}$ No artigo "O modus operandi ditatorial e a necessidade de revisão do conceito de segurança nacional" discuti-se como, por meio da modificação do conceito da Lei Segurança Nacional, foi possível ao estado brasileiro considerar seus próprios cidadãos como ameaça, e, assim, com a introdução dessa perspectiva, sujeitar a administração pública e a educação brasileira a um modo de agir autoritário.
} 
da natureza, notadamente as florestas nos anos 1960, bem como o contexto histórico em que essas políticas foram forjadas.

Dessa forma, por meio de uma revisão bibliográfica, de uma reconstrução histórica e da análise normativa, propõe-se uma revisita ao ambiente político que vigorava quando da edição de leis que se relacionavam com o Código Florestal outorgado em 1965 (Lei n ${ }^{\circ}$. 4.771/65), o segundo Código Florestal da história do Direito Brasileiro. Isso porque é comum, na análise de julgados e leis, desconsiderar o seu contexto histórico-político, como se a sua criação fosse um evento técnico e desvinculado da realidade política.

\section{0 contexto da década de 1960}

O século XX foi sem dúvida um século de mudanças intensas no planeta. A década de 1910, que abrange a Primeira Guerra Mundial, pode ser considerada a de maior relevância para a difusão mundial da luta pelos direitos sociais dos trabalhadores, basta lembrar a criação da Organização Internacional do Trabalho (OIT), a Constituição Mexicana e a Revolução bolchevique. A crise de 1929, por sua vez, trouxe à tona a evidencia de que a "mão invisível do mercado" não era assim tão hábil a ponto de prescindir da intervenção estatal. A primeira metade da década de 1940 foi um período de horror e desumanidade com as atrocidades do nazi-fascismo e o lançamento de bombas atômicas sobre Hiroshima e Nagasaki pelos EUA.

Sob a perspectiva da revolução dos costumes, a década de 1960 talvez tenha sido a de maior ebulição política no século XX, com o advento de novas ideias como a defesa do meio ambiente, o feminismo, a igualdade racial, os direitos do consumidor, o questionamento do modelo tradicional da relação professor e aluno nas universidades, a expansão do uso de drogas, as campanhas de paz no Vietnã, o aparecimento de legislações em defesa das pessoas com deficiência e etc.

As lutas pelo poder se deram em torno da guerra fria, revelam muito da disputa ideológica envolvida. No caso brasileiro, a década de 1960 ficou longe de constituir um avanço civilizacional ou representar um momento de conquistas democráticas. Pelo contrário, após um breve interregno de protagonismo popular, a continuidade histórica hegemônica de parcela privilegiada da elite impôs-se, como se verá a seguir. 
A referida hegemonia ideológica vigente nesse período caracteriza-se, principalmente, no que diz respeito ao trato com a natureza, por uma disposição contínua de subjugação desta, o que remete à constatação de que o Código Florestal de 1965 serve a esse propósito.

Para compreender o contexto anterior à década de 1960, o saudoso professor Guido Fernando Silva Soares (2003, p. 42), ensinava que "[...] no século XX, antes da grande guerra, as convenções internacionais sobre temas do meio ambiente eram eminentemente utilitárias e diziam respeito ao comércio mundial de certas espécies animais, com finalidade de preservação dos indivíduos, para fins de exploração econômica", isso porque não se pretendia o equilíbrio ecológico ambiental mas de regulação do "mercado", embora o professor se referir ao período anterior à Segunda Guerra, quando da preparação para a primeira grande convenção ambiental mundial em 1972, essa perspectiva mercadológica, ainda se fazia presente (2003, p. 53), “[...] era evidente a oposição entre países desenvolvidos e em desenvolvimento", os primeiros, querendo criar instrumentos que prevenissem os desequilíbrios ambientais causados nos séculos anteriores pelo "[...] desenvolvimento industrial caótico, na Europa Ocidental, nos EUA e Japão", e os segundos “[...] opuseram-se a que as eventuais políticas preservacionistas adotadas pudessem servir de instrumento de interferência externa".

Entre estes últimos, encontrava-se o Brasil que buscava uma política "desenvolvimentista". A justificativa de buscar o "desenvolvimento" a partir da "dominação da natureza", a qualquer custo, bem como considerar os bens ambientais como se fossem o "seu estoque", do qual o Estado poderia se servir e explorar sem quaisquer preocupações, não era novidade. Conforme os professores Vicente de Paula Barreto e Fabio Beltrame já estava presente nas ideais dos iluministas (2016, p. 1482):

\begin{abstract}
Encontra-se em Descartes e noutros pensadores os indícios da ruptura entre homem e natureza. No entanto, tamanha ruptura, remonta à origem da espécie humana, pois desde então o homem intervém e transforma a natureza. O homem humaniza a terra, reveste-a de símbolos que a fazem falar uma linguagem para ele inteligível, o homem imprime a sua marca na terra, esta é a característica do homem moderno, a liberação das amarras cosmológicas e a sensação de dominação da natureza como um primado do homem, que o fazem procurar e adequar o ambiente natural a seus desejos, diferentemente do homem primitivo que não se arriscava a perturbar a ordem do mundo, não somente por medo de uma punição dita divina, mas por uma sensação de pertencimento àquele universo, onde natureza e sociedade, grupo e indivíduo, coisa e pessoa praticamente não se distinguem.
\end{abstract}

No mesmo sentido, Luís Roberto Barroso (2013, p.74-78), referindo-se aos conceitos fundamentais do Iluminismo, afirma que "[...] no 'reino dos fins' tudo teria um preço ou uma dignidade, esta, para as pessoas, aquela para as coisas". Por essa perspectiva, a natureza encontra-se com um status 
de menor importância e proteção, pois, como a dignidade é atributo apenas de humanos, os bens ambientais terão preço, porque não guardariam identidade com o homem, logo só possui a dignidade aquele ou aquilo ao qual a lei conferir uma identidade, tal qual a humana.

O problema é que, nesse sistema, o que elege quem tem identidade com a condição humana é a lei, e quando ela é produzida por legisladores que não veem a natureza, no caso específico, as florestas, como alguma coisa com o que se identifiquem, eles poderão atribuir a elas um "preço", um bem de valor econômico, como dizem os administradores, um "estoque disponível”.

Isso não é por acaso, mas para atender a um propósito específico, a imposição de uma ideologia, para Marcelo Abelha (2005, p. 72) “[...] o liberalismo econômico, que tinha como interesse maior considerar o meio ambiente como simples riqueza (matéria-prima) inesgotável como se fosse res nullius".

Diante disso tudo, imaginar que 1965 quando da edição do Código Florestal se produziria uma legislação de proteção específica das florestas a partir do reconhecimento de seu valor intrínseco e não de maneira utilitarista não é condizente com o contexto histórico político brasileiro da época. O período histórico aqui recortado, sob essa referência ideológica, produziu políticas públicas que deixaram muito claras as perspectivas que tinham da dominação do outro e da natureza.

Este paradoxo entre a narrativa histórica e a norma, no caso o Código Florestal de 1965, está presente, desde os tempos mais remotos da cultura, pode-se ver a dissociação entre existência humana e natureza na transição entre o período homérico e o aristotélico.

\subsection{O naturalismo}

A ideia naturalista, na qual tudo seria ditado por uma lei advinda da natureza, inexorável e que determinava a ordem "natural" e o destino das coisas ${ }^{7}$ começa a dissolver a confusão entre o sagrado, o profano, o caos, o acaso, a relação dos deuses com os homens, com semideuses e com toda sorte de seres mitológicos.

Coube aos filósofos separar tais elementos nos primórdios. O precursor dessa experiência foi Tales de Mileto (624 a.C. - 558 a.C.), que estabeleceu um marco na história do pensamento que permanece ainda contemporaneamente como paradigma.

\footnotetext{
${ }^{7}$ O Estado de arte desse período do pensamento, conforme Carlos Eduardo Bittar e Guilherme Assis de Almeida (2015, p. 73), “[...] se preocupava em buscar uma explicação a respeito da ordem natural, sobre o surgimento do mundo, tentava desvendar quem era e onde estava a partir da observação da natureza" ou, ainda, segundo Souza e Kuhnen (2005, p. 25) "[...] a ação que de si gerava tudo, a chama eterna que se acende e se apaga sem cessar".
} vol.12,n'.04, Riode Janeiro, 2019.Pp.306-325 


\subsubsection{Tudo é água}

Tales concentrou todo o debate a respeito da "origem" da natureza na seguinte expressão (NIETSZCHE, 2008, p. 43): “[...] a água é a origem, é como útero materno de todas as coisas”. Essa frase é fantástica por vários motivos. O primeiro deles porque se desconsidera a existência de algo (a água) das fabulações míticas anteriores e se passa a considerar essa coisa em si mesma, já que ela teria dado início a tudo. Portanto, a água, por ser a origem, passou a simbolizar a representação linguística de uma unidade daquilo que existe.

Houve, ainda, outros filósofos que atribuíram "a origem" a outros elementos, por exemplo: Anaxímenes, para quem o início se dava no ar; Empédocles, para quem a terra, o fogo, o ar e a água se misturavam dando origem às substâncias, às misturas; e, para Demócrito, o universo era vazio de fragmentos vazios (átomos).

\subsubsection{O que há por trás da água?}

Foi com Heráclito (535-475 a.C.) que o sentido da expressão ganhou forma, novas características, a água passou a ser vista de maneira fluida, ${ }^{8}$ mutável, em dias atuais, uma certa malemolência. Essa nova perspectiva abriu a possibilidade de aprofundar a ideia de que uma coisa (a água) não encerraria em si uma essência, pois haveria ainda outra coisa "por detrás da água" e, como resultado final dessa conjectura, pretendia-se ver para além dela e, assim, a umidade precederia a água que, por sua vez, seria composta pelo quente e pelo sólido, experimentações preliminares à própria água.

Ele descreveu ainda (NIETSZCHE, 2011, p. 77) “[...] a terra em oposição ao fogo, o espesso ao fino, o quente ao frio, o feminino ao masculino, cindiu o mundo empírico em esferas separadas", ${ }^{9}$ dando azo ao modo embrionário da ideia de que os opostos se atraem e se repelem coexistindo, de modo que aquilo que existe sucumbirá da mesma forma que aquilo que virá a ser ainda inexiste, num movimento que os torna parte da mesma coisa (uno).

Dessa especulação se percebe a confusão ainda entre o conceito de existência e inexistência, conceitos conexos, em que um depende do outro. Essa formulação parecia verossímil, até que

\footnotetext{
8“'Tu não podes descer duas vezes no mesmo rio porque novas águas correm sempre novamente sobre ti” (SOUZA; KUHNEN, 2005, p. 25, fragmento D. 12), demonstrando, assim, o caráter mutável tanto da água como de todas as coisas.

${ }^{9}$ A primeira esfera para coisas "existentes" que devem ser buscadas diante de nós, em nosso mundo, até no horizonte e não além; e a outra destinada às coisas "inexistentes" que dão origem às qualidades ocultas.
} 
Parmênides intuiu a desconexão entre existir e não existir ou, como diria Shakespeare muitos séculos depois, a questão de a coisa "ser" ou "não ser".

\section{A relação entre o argumento parmenidiano e o Código Florestal}

Para exemplificar a tal desconexão, Parmênides (530 a.C.-460 a.C.) utilizou um exemplo muito simples, que nos remete ao objeto do código em questão, uma vez que usava a árvore como exemplo que pode ser potencializado para a floresta. Ei-lo:

Imagine-se uma árvore. A respeito dela pode-se dizer: a) "ela é”, se comparada com outras árvores existentes; b) "ela não é uma árvore”, se a identificarmos apenas como um arbusto, um broto; c) e, ainda, "ela virá-a-ser" (devir), quando a imaginamos em outro tempo futuro. Portanto, pode a árvore (a coisa) ser em si mesma, pode ser em relação a outras ainda que não o seja efetivamente neste momento. Essa formulação original levou ao entendimento de que existir independe de uma essência natural, era o desprendimento da existência em relação à natureza. ${ }^{10}$

Finalmente, chega-se ao fim da justificação do título do artigo. Tantos séculos após, apesar dos argumentos evolutivos, encontramo-nos ainda estagnados nessa mesma questão no Código Florestal, qual seja: afinal, seu objetivo é preservar águas e florestas por direito próprio ou em função da utilidade econômica que podem representar para a existência humana?

No que diz respeito à política de preservação das florestas, sua manutenção parece sempre estar vinculada a um fim, que não a de sua própria preservação. Como exemplo, cite-se a obrigação ali criada de se conservar as áreas de preservação permanentes (APPs), principalmente aquelas que determinam a manutenção de matas ciliares. ${ }^{11}$ Grosso modo, o que se pretende é a manutenção do fluxo hídrico, impedir que os rios assoreados sequem, tanto que, nos programas de recuperação de bacias hidrográficas, se remuneram os "produtores de água" a partir da regeneração das respectivas matas ciliares dos corpos d'agua que cortam as propriedades.

No que diz respeito à política nacional de recursos hídricos, ${ }^{12}$ não há sequer disfarces, pois o valor econômico para a água está expresso na lei.

\footnotetext{
${ }^{10}$ Com Parmênides (NIETSZCHE, 2008, p. 88), pai da ontologia (estudo do Ser) "[...] a busca por uma essência natural se esmaece, perde muito de seu sentido, na medida em que passou a considerar que o existir nada tem que ver com a essência, ou seja, não se pode identificar a essência do ser simplesmente em função de existir, há de se ter algo para além, o inexistente".

${ }^{11}$ Obviamente, os autores não são contra a designação de áreas de proteção ambiental. O objetivo da referência é citá-las como exemplo da perspectiva utilitária da legislação florestal.

${ }^{12}$ Lei $n^{\circ} 9.433 / 97$, que estabelece, em seu art. $1^{\circ}$ II, que a água é um bem natural limitado e dotado de valor econômico.
} 
Esses exemplos demonstram que a pretensão do legislador da época foi desenvolvida de maneira utilitarista, ${ }^{13}$ ou seja, como um equipamento produtor de água, deixando de ter um sentido de "originalidade" natural, para ter um sentido "atribuído" pela ciência. A ciência produziu um sentido próprio para a floresta. Passa a existir, então, uma relação hierárquica, tanto que seu uso será esquadrinhado em seus mínimos detalhes, como se verá a seguir.

Mas como a ciência se tornou o paradigma?

\section{A ciência como premissa}

O positivismo, na virada do séc. XIX para o XX tinha a missão de soterrar o dogmatismo religioso em toda a Idade Média na Europa. No Brasil, sob forte influência de Augusto Comte já era hegemônico durante a sua transformação em Republica e tornava a fé no progresso da ciência um paradigma, uma crença, uma seita. ${ }^{14}$

O louvor a uma ciência positivista do direito hegemônica que, no início do século passado, mirava o futuro com o slogan "Ordem e progresso", progrediu como método e, para adquirir o verniz da modernidade, atualizou o velho e desgastado slogan com expressões como "desenvolvimento sustentável”, "gestão estratégica", "compliance” e a existência em metros, em centímetros e, por que não dizer agora, em nanomedidas.

A crença no progresso científico, como solução das mazelas humanas, irradiou-se para os problemas ambientais que surgiram no decorrer do século XX, encontrou solo fértil e continua a influenciar profundamente a cultura jurídica e legislativa brasileira, exemplo dessa forte influência/crença, é a criação do Cadastro Ambiental Rural (CAR), que esquadrinha a utilização, via satélite, da propriedade e das florestas como uma suposta garantia do equilíbrio ambiental.

A utilização da exigência de CAR como exemplo não tem a intenção de criticar, mas apenas demonstrar sua origem científica e positivista. ${ }^{15} \mathrm{~A}$ fé no progresso tecnológico/científico como

\footnotetext{
${ }^{13}$ Para fazer um contraponto a essa visão utilitária da floresta, recomenda-se um estudo a respeito de uma dimensão diferente da narrada aqui, baseada na relação do indígena com as florestas. A obra de Eduardo Viveiros de Castro é fundamental para uma compreensão dessa questão, não vinculada ao interesse utilitarista. Dentre outras: A inconstância da alma selvagem, da Cosac-Editora, ou, ainda, os vídeos disponibilizados nas redes sociais: A morte como quase acontecimento e $O$ pensamento indígena amazônico.

${ }^{14}$ Sobre a influência do positivismo na formação da República, é indispensável a obra de José Murilo de Carvalho, A formação das almas, editada pela Cia. das Letras.

${ }^{15}$ Essa observação é somente para marcar a distinção entre as opções do legislador. Ele poderia simplesmente ter criado a obrigação de um cadastro e acreditar na ética e na boa-fé do proprietário para realizar a tarefa. Entretanto, ele optou por criar uma ferramenta moderna e científica, caríssima, diga-se de passagem, ao regulamentar a norma. Novamente, só estamos apontando a origem científica da norma positivada, sem fazer juízo de valor a respeito.
} 
solução só aumenta, como se sabe, os problemas de demarcação, grilagem e registro de terras no Brasil são centenários e não há segurança jurídica alguma quanto à delimitação das propriedades rurais, o manejo da tecnologia de ponta, ainda que feito por um órgão sem verbas e sem funcionários é visto como solução.

Esse tipo de confissão de fé na ciência passa por um processo que se inicia com a divinização de seus cânones, para, na sequência, lhes atribuir a chancela da aprovação científica e, somente então, obter, como resultado final, sua materialização em forma de normas jurídicas.

Entretanto, mesmo com toda essa crença no desenvolvimento tecnológico e em suas promessas, apesar de todos os apelos éticos que as questões ambientais envolvem, percebe-se, na história das últimas décadas, as mais modernas, as tragédias ambientais só fazem aumentar e se tornam cada vez mais graves, ${ }^{16}$ entretanto, quando são anunciadas, atribui-se ao caos natural e não ao progresso tecnológico sua origem, é como se o progresso científico materializado nas indústrias e nas alucinantes formas de produção em massa fossem "neutros", não causassem consequências.

Assim, o positivismo científico, acaba por se tornar ele mesmo uma divindade, um mito, um oráculo; mas não exatamente como na Antiguidade, na medida em que agora, o que o legitima é lei e não mais as divindades.

\section{0 estilhaço histórico}

Fixada a premissa, deve-se retornar à atmosfera política do que se chama aqui de "estilhaço histórico". ${ }^{17}$ Havia, no Brasil do início da década de 1960, uma grande participação de movimentos populares, notadamente as comunidades eclesiais de base, que almejavam a emancipação libertadora dos pobres com a implantação do primeiro Plano Nacional da Educação que, sob a batuta de Anísio Teixeira (então ministro da Educação), de Darcy Ribeiro, Florestan Fernandes Jr., dentre outros, que objetivava implantar o método desenvolvido por Paulo Freire, louvado até hoje como a maior referência educacional do mundo.

Evidência disso é que, nos anos 1950 (LEITE, 1999, p. 40), houve a Campanha Nacional de Educação Rural (CNER) e a criação do Serviço Social Rural (SSR), com a consequente mobilização das populações rurais, sindicatos rurais, ligas camponesas e movimentos sociais em favor dos

\footnotetext{
${ }^{16}$ Momento no qual é oportuno citar a tragédia ambiental do caso Samarco, tido como o maior desastre ambiental brasileiro, ocorrido em 2016.

17“"Estilhaço" é uma alusão à expressão benjaminiana que se refere a estilhaços do tempo, uma referência a um interregno de tempo, ainda que efêmero, em que a continuidade histórica é rompida por uma revolta dos oprimidos, por exemplo, a Revolução Francesa, que acabou com mais de mil anos de reinados medievais.
} 
menos favorecidos. Articulados com a Igreja Católica, desenvolveram uma proposta educacional, o Movimento Educacional de Base (MEB), sempre lastreados por experiências exitosas da educação emancipadora de Paulo Freire no interior nordestino.

Esses movimentos partiam de uma visão de agricultura familiar, numa perspectiva de pequena escala, diversa e em harmonia ecológica, de modo que a produção não seria baseada em objetivos unicamente mercantilistas, mas, principalmente, de emancipação. Isso fez com que imensas massas populares começassem a pressionar por aquilo que se chamava na época de "reformas de base", que se constituíam na reforma da educação e na reforma agrária, e encontraram em João Goulart (Jango) um candidato disposto a realizá-las.

Entretanto, os poderes hegemônicos reagiram e, por meio de um golpe político, apagaram com violência o "estilhaço histórico" que se insinuava. Após o golpe, em $1^{\circ}$ de abril de 1964, o AI-1 (Ato Institucional $\mathrm{n}^{\mathrm{o}}$ 1), em seu art. $7^{\mathrm{o}},{ }^{18}$ cassou os direitos políticos dos opositores ${ }^{19}$ e marcou uma radical transformação no modelo educacional, que passa a desprestigiar a educação rural, campesina de educação popular, para torná-la, para recuperar um termo do positivismo, mais "científica".

De acordo com Regina Celi Frechiani Bitte (2006, p. 44, grifos nossos),

[...] criou-se uma visão tecnicista da educação, baseada no modelo administrativo das grandes empresas e vinculando a educação ao progresso técnico e científico, contrário à autonomia universitária, ideia essa tida como contrária à falta de disciplina e autoridade, prejudicial à ordem e à democracia.

Com isso, os autores do golpe de 1964, tornaram-se responsáveis pela perda do bonde da história educacional no Brasil ao desmontar as estruturas educacionais rurais e desprezar as inovadoras experiências vivenciadas naquela época.

\footnotetext{
${ }^{18}$ Art. $7^{\circ}$ : "Ficam suspensas, por 6 (seis) meses, as garantias constitucionais ou legais de vitaliciedade e estabilidade. $\S 1^{\circ}$ - Mediante investigação sumária, no prazo fixado neste artigo, os titulares dessas garantias poderão ser demitidos ou dispensados ou, ainda, com vencimentos e as vantagens proporcionais ao tempo de serviço, postos em disponibilidade, aposentados, transferidos para a reserva ou reformados, mediante atos do Comando Supremo da Revolução até a posse do Presidente da República e, depois da sua posse, por decreto presidencial ou, em se tratando de servidores estaduais, por decreto do governo do Estado, desde que tenham tentado contra a segurança do País, o regime democrático e a probidade da administração pública, sem prejuízo das sanções penais a que estejam sujeitos".

${ }^{19}$ Como consequência, foram cassados 7 reitores das 25 universidades federais existentes, quase 500 deputados e 2.000 funcionários públicos. Foram expulsos ainda de suas cátedras 66 professores universitários, dentre os quais Caio Prado Jr., Florestan Fernandes e Fernando Henrique Cardoso. Além disso é preciso divulgar a edição do famigerado Decreto ${ }^{\circ} 477$, verdadeiro ato institucional que perseguiu e puniu milhares de estudantes, proibindoos de permanecer nas universidades. Pelo menos de 46 deles não se sabe o paradeiro até hoje.
} 
A trágica interrupção do Plano Nacional de Educação de Anísio Teixeira e Paulo Freire é sentida até os dias atuais, na medida em que, 50 anos após o golpe, ainda se constitui no principal anseio cobrado pela sociedade, pois não há uma só reivindicação política que não passe pela restauração da educação.

\section{0 retorno à continuidade histórica: leis "reformistas" da ditadura}

Com a deposição, em 9 de abril de 1964, de Anísio Teixeira, a invasão por dois mil soldados do principal símbolo emancipatório, a Universidade Federal de Brasília (UnB), conforme depoimento de Marcia Bodanzky, e ainda no contexto da promulgação das Leis $n^{\circ} .5 .540 / 68$ e $n^{0} .5 .692 / 71$, que reformavam o ensino médio e superior, respectivamente. Promoveu (LEITE, 1999, p. 48,71), por exemplo, a substituição da professora do ensino regular e formal no campo por técnicos extensionistas, com o objetivo de "[...] aumentar a produção agrícola estimulando a difusão da tecnologia agrícola e promover a modernização da agricultura".

Como consequência, abriu-se, a maior das chagas brasileiras da qual o país jamais se curou, o analfabetismo, que campeou na sociedade rural, e com ele a alienação política, o obscurantismo e o isolamento. Prova dessa política centenária e contínua de manutenção do analfabetismo é que (FERRARO, KREIDLOW, 2004, p. 178) no censo realizado em 1890, constatou-se que 82,6\% da população era analfabeta e que, na década de 1960 (O GLOBO), o Brasil continuava a ser um país com $68 \%$ de analfabetos no campo (que representava $46 \%$ da população).

Esse fardo ficou pesado demais, mesmo para a ditadura, tanto que, nos tempos finais, na década de 1980, programas e projetos foram implantados de modo a diminuir o problema que, a essa altura, já era alarmante, como o programa de Educação Rural (Edurural) e o Movimento Brasileiro de Alfabetização (Mobral).

Somente com o retorno da democracia, nos anos 90, novamente por esforço daqueles que em 1964 foram expulsos do país, dentre os quais, Darcy Ribeiro, outrora Chefe da Casa Civil do Presidente deposto João Goulart e fundador da Universidade de Brasília, agora eleito senador, consegue aprovar a nova Lei de Diretrizes e Bases da Educação em 1996, responsável por agendas destinadas a uma educação específica para o campo, até que, em 2002, o Conselho Nacional de Educação, pela Resolução CNE/CEB n 1, de 3 de abril de 2002, traça as Diretrizes Operacionais para a Educação Básica nas Escolas do Campo. 
Defende-se aqui que nada disso foi por acaso, antes fez parte de um modus operandi, cujo objetivo era enfraquecer ou abandonar o povo do campo, pois, com a dificuldade de educação no campo, a migração para as cidades aparece como a única alternativa.

Essa estratégia de governo foi adotada porque, em todo o mundo, principalmente em 1968, estouravam revoltas a partir do campo, como na Rússia, China, Coreia, Vietnã, El Salvador, Cuba, Bolívia, e o regime temia que aqui igualmente surgissem revoltas camponesas, ${ }^{20}$ por isso a duríssima repressão, por exemplo, àquela que historicamente ficou conhecida como Guerrilha do Araguaia, ainda que tenha sido um massacre, conforme já reconhecido inclusive pela Corte Interamericana de Direitos Humanos.

Não é por outro motivo que, também aqui, no Brasil, a repressão no campo foi brutal. De acordo com a lista divulgada pela Secretaria de Direitos Humanos da Presidência da República em 2013, foram pelo menos 1.928 camponeses mortos ou desaparecidos políticos em função da disposição de lutar pelas políticas de reforma agrária. Pode-se citar a Guerrilha do Araguaia, na qual o Exército brasileiro exterminou pelo menos 75 pessoas em uma só ação, conforme reconhecido pela Corte Interamericana de Direitos Humanos, como se pode verificar no Relatório da Comissão Nacional da Verdade.

As leis de reforma do ensino secundário e superior acima citadas, assim como o Estatuto da Terra (Lei $n^{\circ}$. 4.504/64) e o Código Florestal (Lei n4.771/65), e ainda a legislação produzida a partir daí são frutos do autoritarismo, típicos dos regimes militares de viés capitalista, mas com um verniz de modernidade, principalmente com uma nomenclatura ilusória, por exemplo, "aumento da produção agrícola com a difusão da tecnologia", "combate ao analfabetismo", "reforma agrária" e "florestas como vegetação, como bem de interesse comum de todos os habitantes do país".

$\mathrm{Na}$ verdade, os referidos diplomas criaram imensas obrigações e dificuldades na distribuição de terras ou concessões para o pequeno agricultor e camponeses, com o objetivo de minar as possibilidades de sua organização, embora pintada com o já referido "verniz modernista", ao admitir

\footnotetext{
${ }^{20}$ Como prova dessa predisposição por uma revolução a partir do campo, digna de nota é a carta de Carlos Marighella à direção do Partido Comunista brasileiro e a Fidel Castro, na qual manifesta a sua disposição pela luta de guerrilha a partir dos seguintes termos:

Não estou preocupado em construir outro partido para ficar na cidade, “[...] para mim, chegou o momento em que as forças revolucionárias devem concentrar-se na área rural. O papel de uma direção proletária, marxistaleninista, pelo menos na América-Latina, é estar no campo e não na cidade [...] segundo penso, a luta guerrilheira é a única maneira de unir os revolucionários brasileiros e de levar nosso povo à conquista do poder. Recursos humanos e condições para guerrilha não faltam ao Brasil. A consciência que brota da luta se encarregará dos demais. A guerrilha é o mais anticonvencional e antiburocrático que pode haver, o que mais se afasta do sistema tradicional de um partido da cidade" (PRESTES, 2015, p. 410).
} 
a função social da terra como princípio, não havia a pretensão de cumprir nada disso. É ingenuidade acreditar que o regime que foi extremamente violento no campo, que exterminava a oposição como política pública controlada pelo próprio gabinete "presidencial", ${ }^{21}$ no Congresso iria propor uma legislação que protegesse a natureza e o ambiente.

Não ineficácia do Código Florestal de 1965, foi anunciada e ela deve ser a norma jurídica mais descumprida em território brasileiro, a descrença de alguns deputados virou profecia e foi registrada. Pedro Avzaradel (2016, p. 23) resgatou o discurso do deputado João da Veiga que questionava: “[...] Senhor Presidente, sábio orientador e verdadeiro que é este Código Florestal, será ele cumprido? Que destino terá esse código quando meia dúzia de funcionários terá que fiscalizar, a segunda floresta do mundo?"

Assim como desacreditavam os deputados da eficácia do Código Florestal, supor que o ditador Castelo Branco como um "reformista agrário" ao promulgar o Estatuto da Terra, principal bandeira eleitoral de Jango e argumento que justificou sua deposição, é incompatível com sua biografia repressora.

A aura reformista governo militar, quando posta em prática, produziu, como consequência conforme Marés (2003, p. 110), “[...] a manutenção e o incremento da tradição latifundiária, e na essência manteve intacta a ideologia da supremacia da propriedade privada sobre qualquer benefício social", concentrando a renda no campo para um número ainda mais reduzido de latifundiários.

As consequências dessa tática foram perversas, resultando em enormes dificuldades para o processo de distribuição de terras ou concessões para fins de reforma agrária para o pequeno agricultor.

Para demonstrar isso, basta comparar as imensas barreiras procedimentais nos processos de desapropriação para fins de reforma agrária por descumprimento da função social da propriedade ou, ainda, dos processos de reconhecimento de propriedades de comunidades ancestrais com a agilidade de um grande latifundiário para conseguir um financiamento público de lavoura ou sua escrituração. Para estes, horas; para aqueles, anos.

\section{A imposição do modelo tecnocrata na educação pelo regime militar}

\footnotetext{
21 Prova do conhecimento e autorização do Gabinete Presidencial dos horrores perpetrados nos porões exterminadores da ditadura foi a recente divulgação de relatório secreto do governo do E.U.A. que demonstra que os generais Ernesto Geisel e João Batista Figueiredo sabiam, enquanto “presidentes”, e concordavam com as mortes, conforme demonstra a reportagem disponível em:

$<\quad$ https://www1.folha.uol.com.br/poder/2018/05/chefe-da-cia-disse-que-geisel-assumiu-controle-sobreexecucoes-sumarias-na-ditadura.shtml $>$. Acesso em 15 jun.2018
} 
O regime militar em sua estratégia de marketing adotou um slogan típico dos positivistas do início do século (como se verá na sequência), ao chamar de "milagre econômico" as políticas de modernização das lavouras e das indústrias, o uso de agrotóxicos (novidade tecnológica da época) e a utilização de subsídios agrícolas, todas práticas atreladas ao "progresso científico".

A pretensão de extirpar o "bolsão bolchevista” produziu o extermínio sistemático de todo geração de membros da esquerda brasileira. No dizer Ana Cristina Hammel, Gelson Kruk da Costa e Ivone Meznek:

Os militares se apoiaram em duas correntes ideológicas para legitimar seu governo: a ideologia da ordem e a tecnocrática. A primeira representava a corrente hegemônica civil-militar, que assumia o poder em nome da segurança nacional e da paz social; a segunda assentava-se num economicismo monetarista e tinha como representantes os líderes dos setores técnicos do governo comprometidos com a promoção do desenvolvimento econômico.

Assim, a ideologia tecnocrática passou a orientar também a política educacional definida nos planos globais de desenvolvimento nacional elaborados pelos técnicos do Ministério do Planejamento. Os tecnocratas, contudo, passaram a ser influenciados pelos militares que assumiram, implicitamente, os interesses econômicos do complexo empresarial. Essa ideologia foi tomando, posteriormente, com características de uma ideologia tecnocrático-militar. Dessa forma, dentro da ótica do mercado de trabalho, os militares planejaram um sistema educacional que, por um lado, o ensino médio, atendesse às massas e, por outro lado, o ensino universitário, fosse reservado às elites, assim, advogava-se publicamente a profissionalização da escola média com objetivos de contenção das aspirações ao ensino superior. Pode-se dizer, portanto, que, ao contextualizar a ditadura militar e as influências na educação nacional, passa-se por entender a lógica governamental de um grupo da elite, com grande poder repressivo, amplamente comprometido com a burguesia.

Essa perspectiva, aliada a um poder executivo forte e intervencionista é condizente quando comparada com as concepções dos militares protagonistas da transformação do Brasil em República, tanto quanto nos que impuseram o golpe militar de 1964, segundo o historiador José Murilo de Carvalho (1990, p. 10) os assim denominados os positivistas

[...] obtiveram maior sucesso em manipular o imaginário popular com vistas à implantação de sua política. As heranças de Comte estão presentes, por exemplo, ainda hoje na bandeira brasileira, na divisa 'ordem e progresso', na hegemonia de um executivo forte e intervencionista, na valorização da palavra escrita, na alegoria feminista e, sobretudo, quando este se afastou do robespierrismo da revolução francesa do governo do povo, conceito que considerava por demais metafísico.

Foram estabelecidas leis que previam a intervenção do Governo Central em todos os níveis governamentais, estaduais ou municipais, embora os estados tenham podido eleger seus governadores em todo período ditatorial, dando uma aparência democrática ao sistema, o Executivo 
federal mantinha poderes concentrados para garantir o "sucesso" de investimentos estratégicos sobre os quais tinha "interesse", sempre sob o manto da "segurança nacional".

O Poder Central arvorou-se do direito de exclusivamente editar leis regulamentares ambientais. Isso é o que se pode depreender, por exemplo, do Decreto Lei $n^{\circ} 1.413 / 75^{22}$ que, em seu art. $2^{\circ}$, estabelecia competência exclusiva do Poder Executivo Federal para "[...] determinar ou cancelar a suspensão do funcionamento de estabelecimento industrial cuja atividade seja considerada de alto interesse do desenvolvimento e da segurança nacional", conforme contexto descrito pelo eminente professor Roger W. Findley, ainda nos idos de 1988.

A edição do decreto se deu como uma reação do Governo Central assumindo para si, exclusivamente, a competência para "suspender licenças", tendo em vista que o município havia ousado suspender as licenças de uma grande mineradora (de interesse estratégico), após um grave "acidente ambiental".

Segundo o professor, as agências estaduais e municipais até tentavam produzir um controle ambiental mínimo, entretanto eram incapazes, devido à demasiada intervenção, como prova o resgate histórico dos desastres ambientais de Cubatão e do rio Paraíba do Sul, na década de 1980, realizado pelo citado professor.

${ }^{22}$ Presidência da República. Casa Civil. Subchefia para Assuntos Jurídicos. DECRETO-LEI n ${ }^{\circ} 1.413$, de 31 de julho de 1975. Dispõe sobre o controle da poluição do meio ambiente provocada por atividades industriais.

"O PRESIDENTE DA REPÚBLICA, no uso da atribuição que lhe confere o artigo 55, item I, e tendo em vista o disposto no artigo $8^{\circ}$, item XVII, alínea "c", da Constituição, DECRETA:

Art. $1^{\circ}$ As indústrias instaladas ou a se instalarem em território nacional são obrigadas a promover as medidas necessárias a prevenir ou corrigir os inconvenientes e prejuízos da poluição e da contaminação do meio ambiente.

Parágrafo único. As medidas a que se refere este artigo serão definidas pelos órgãos federais competentes, no interesse do bem-estar, da saúde e da segurança das populações.

Art. $2^{\circ}$ Compete exclusivamente ao Poder Executivo Federal, nos casos de inobservância do disposto no artigo $1^{\circ}$ deste Decreto-lei, determinar ou cancelar a suspensão do funcionamento de estabelecimento industrial cuja atividade seja considerada de alto interesse do desenvolvimento e da segurança nacional.

Art. $3^{\circ}$ Dentro de uma política preventiva, os órgãos gestores de incentivos governamentais considerarão sempre a necessidade de não agravar a situação de áreas já críticas, nas decisões sobre localização industrial. Art. $4^{\circ}$ Nas áreas críticas, será adotado esquema de zoneamento urbano, objetivando, inclusive, para as situações existentes, viabilizar alternativa adequada de nova localização, nos casos mais graves, assim como, em geral, estabelecer prazos razoáveis para a instalação dos equipamentos de controle da poluição.

Parágrafo único. Para efeito dos ajustamentos necessários, dar-se-á apoio de Governo, nos diferentes níveis, inclusive por financiamento especial para aquisição de dispositivos de controle.

Art. $5^{\circ}$ Respeitado o disposto nos artigos anteriores, os Estados e Municípios poderão estabelecer, no limite das respectivas competências, condições para o funcionamento de empresas de acordo com as medidas previstas no parágrafo único do artigo $1^{\circ}$.

Art. $6^{\circ}$ Este Decreto-lei entrará em vigor na data de sua publicação, revogadas as disposições em contrário. Brasília, 14 de agosto de $1975 ; 154^{\circ}$ da Independência e $87^{\circ}$ da República". 
A falta de vontade política para exigir grandes despesas ambientais das empresas instaladas, sempre com o objetivo de manter-se como um país atrativo para investimentos, era manifestada claramente pelo ditadura, sob a perspectiva de que "[...] um país em desenvolvimento, não pode se dar ao luxo de alocar escassos recursos públicos e privados para a proteção ambiental, e que atividades produtivas não deveriam ser obrigadas a cumprir novas exigências e normas, sem ajuda financeira pública" (FINDLEY, 1998, p. 31).

\section{O Judiciário de "costas" para as questões ambientais}

Como ressaltado na introdução, após 47 anos de ineficácia do Código Florestal de 1965, foi instituído um "novo" Código em 2012, que mantém a mesma ideologia comentada, qual seja, submeter os bens ambientais, no caso as florestas, ao mercado. Com esse intuito, a proteção das faixas marginais dos rios foi diminuída sistematicamente e os outrora criminosos ambientais foram anistiados, atendendo, assim, aos interesses da bancada ruralista, hegemônica no Congresso Nacional.

Questionada a constitucionalidade dos dispositivos que estabeleciam tais disparates, em função de violar o princípio da proibição de retrocesso, foram ajuizadas a ADC 42 e as ADIs 4901, 4902, 4903 e 4937.

O voto condutor do ministro Celso de Mello, contrariando a prolixidade que lhe é habitual, rechaçou a tese de violação do princípio da proibição de retrocesso manejado nas referidas ações, com o simplório argumento de que, embora o admitisse em tese, no caso concreto, o STF não poderia "constranger a liberdade da casa legislativa".

Mais do que contestar o mérito da causa, sobre a eventual inconstitucionalidade da norma, o que se quer aqui é ressaltar a falta de disposição do Judiciário, no caso o STF, em assumir o seu papel contramajoritário de guardião da Constituição Ambiental, especialmente quando a maioria hegemônica capaz de mudar a lei no Congresso Nacional, tanto em 1965 quanto agora, é ruralista.

Nessa perspectiva (hegemônica), a diminuição da faixa de proteção das APPs é vista como um "não retrocesso", ainda que isso contrarie a lógica, pois, obviamente não se pode reduzir a faixa de proteção marginal dos corpos d'agua estabelecida desde 1965, sem consequentemente diminuirlhes a proteção, como previsto na Lei de 2012.

Assim, o que justifica a referida ausência lógica é a crença, a fé cega, de que tais alterações são inócuas, neutras. A verossimilhança é suficiente, ou seja, a aparência de verdade, é suficiente para aquele que guarda professa a fé de que o progresso científico. O desejo de que soluções tecnológicas 
encontrarão uma compensação para essa perda de proteção produz a justificação da alegação, ou seja, a fé no dogma basta para se lhe atribuir veracidade e correção.

Mas ressalte-se, se a decisão é apenas fruto de um desejo, ela revela uma imanência de quem a profere, um desejo de dominação por parte de quem profere a decisão, de escravização dos outros e dos ecossistemas, em seus mínimos detalhes e de maneira tecnológica, assim, pouco importa se a faixa marginal protetora dos recursos hídricos é de 15, 30, 50 ou 100 metros, quando o desejo de dominação é ilimitado.

Como procurou resgatar o artigo, os poderosos hegemônicos de plantão se sucedem sem serem afetados por uma conscientização ambiental, menos ainda pela legislação ambiental, pois desejam dominar, e esse desejo é fruto de uma educação hierarquizada que adestra e não emancipa e que, por isso mesmo, atribui preço a tudo, transforma tudo em produto, seja dignidade, seja água, seja floresta, seja biota, enfim, não admite identidade em outros elementos naturais. Esta falta de alteridade com os bens ambientais é antagônica ao regime democrático, que pressupõe "conspiração" racional e social para que se conviva educadamente e em harmonia uns com os outros, onde a pobreza a exploração e a devastação da natureza são erros que devem ser corrigidos, não por qualquer razão legal, mas porque ser uma marca civilizatória.

Afinal, tudo é água mesmo!

\title{
The beginning, the ends and the means: the Forest Code
}

\begin{abstract}
The 2012 edition of the Forest Code, the object of countless actions of unconstitutionality, represented yet another episode of the legislative setback in protecting the environment in Brazil. The decision for the constitutionality of practically all of its legal provisions by the Federal Supreme Court has produced strong disappointment in all those concerned with the protection of biodiversity in the country. This article revisits, in the form of a bibliographic review, the development of ideas that legitimize the domination, exploitation and simplification of biodiversity, from the Brazilian historical-political context, present since the edition of the Forest Code of 1965 and maintained in the new Diploma of 2012.
\end{abstract}


Keywords: New Forest Code. Unconstitutionality. Federal Court of Justice. Dictatorial modus operandi. Backspace.

\section{Referências}

BRASIL. Presidência da República. Secretaria de Direitos Humanos. Camponeses mortos de desaparecidos: excluídos da justiça de transição. Coordenador Gilney Amorim Viana. Brasília: Secretaria de Direitos Humanos da Presidência da República, 2013.

BARRETO, Vicente de Paula; BELTRAME Fabio. Considerações acerca da Filosofia, Direito e Ecologia. Quaestio Iuris, Rio de Janeiro, v. 9, nº. 3, p. 1474-1494, 2016.

BARROSO, Luís Roberto. A dignidade da pessoa humana no direito constitucional contemporâneo: a construção de um conceito jurídico à luz da jurisprudência mundial. Belo Horizonte: Fórum, 2013.

BENJAMIN, Walter. Aviso de incêndio: uma leitura das teses "Sobre o conceito de história". Tradução de Wanda Nogueira Cadeira Brant, Jeanne Marie Gagnebin e Marcos Lutz Müller. São Paulo: Boitempo, 2005.

BITTE, Regina Celi Frechiani. Formação do professor no curso de História da Universidade Federal do Espírito Santo. In: SIMÕES, Regina Helena Silva; FRANCO, Sebastião Pimentel; SALIM, Maria Alayde Alcânrara (Org.). Ensino da história, seus sujeitos e suas práticas. Vitória: GM Gráfica e Editora, 2006.

BODANSKI Marcia. Reportagem sobre a invasão da UnB em 1964.Disponível em: https://jornalggn.com.br/noticia/o-golpe-de-1964-e-a-universidade-de-brasilia. Acesso em: 15 mai.2018.

FERRARO, Alceu Ravanello; KREIDLOW, Daniel. Analfabetismo no Brasil: configuração e gênese das desigualdades regionais. Educação e Realidade, Porto Alegre, v. 29, n. 2, p. 179-200, jul/dez. 2004.

FINDLEY, Roger W. Pollution control in Brazil. Ecology Law Quarterly, v. 15, jan. 1988 
FREIRE, Paulo. Pedagogia do oprimido. São Paulo: Paz e Terra, 1996.

HAMMEL, Ana Cristina; COSTA, Gelson Kruk da; MEZNEK Ivone. A ditadura militar brasileira e a política educacional: Lei $\mathrm{n}^{\circ} 5.540 / 68$ e $\mathrm{n}^{\mathrm{o}}$ 5.692/71. In: SEMINÁRIO NACIONAL DE POLÍTICAS SOCIAIS, 5. 2011, Cascavel, Anais eletrônicos do $5^{\circ}$. Seminário Nacional de Políticas Sociais - Unoeste.

Disponível em:

$<\underline{\text { http://cac-php.unioeste.br/projetos/gpps/midia/seminario6/> }}$.

Acesso em: 8 abr. 2018.

HEIDEGGER, Martin. Conferências e escritos filosóficos. Tradução e notas de Ernildo Stein. 4. ed. São Paulo: Nova Cultural, 1991. (Os pensadores; 5)

ISTO É. Disponível em: https://istoe.com.br/bolsonaro-diz-que-ira-acabar-com-demarcacoes-deterras-e-financiamento-de-ongs/. Acesso em: 17 abr. 2018.

LEITE, S.C. Escola rural: urbanização e políticas educacionais. São Paulo: Cortez, 1999.

LEITE, Flamarion Tavares. Manual de filosofia geral e jurídica das origens a Kant. Rio de Janeiro: Forense, 2008.

MAZOYER, Marcel; ROUDART, Laurence. História das agriculturas no mundo: do neolítico à crise contemporânea. Tradução de Cláudia F. Falluh Balduíno Ferreira. São Paulo: Editora Unesp; Brasília, DF: Nead, 2010.

RODRIGUES, Marcelo Abelha, Elementos do direito ambiental. 2. ed. São Paulo: Ed. RT, 2005.

O GLOBO.

Disponível em: < $\underline{\text { http://acervo.oglobo.globo.com/em-destaque/criado-na-ditadura-por-medici-em- }}$

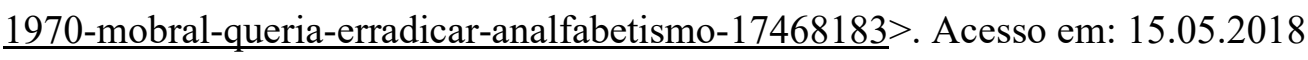

SOARES, Nádia Bolzan. Educação ambiental no meio rural.

Disponível em:

$<$ jararaca.ufsm.br/websites/unidadedeapoio/download/Nadiamono.pdf.>.

Acesso em: 16 de março de 2017. 
SOARES, Guido Fernando Silva. Direito internacional do meio ambiente: emergência, obrigações e responsabilidades. 2. ed. São Paulo: Atlas, 2003.

SUPREMO TRIBUNAL FEDERAL. Memória jurisprudencial: ministro Ribeiro Costa. Organização de Rodrigo de Oliveira Kaufmann. Brasília, 2012.

\section{Relatório final da comissão nacional da verdade.}

Disponível em:

$<$ http://www.memoriasreveladas.gov.br/administrator/components/com_simplefilemanager/uploa ds/CNV/relat $\%$ C3\%B3rio\%20cnv\%20volume_1_digital.pdf. $>$.

Acesso em: 27 abr.2018

NIETZSCHIE, Friedrich. A filosofia na era trágica dos gregos. Tradução de Fernando R. de Moraes Barros. São Paulo: Hedra, 2008.

SOUZA, Jose Cavalcante de; KUHNEN, Remberto Francisco (Org.). Os pré-socráticos: fragmentos, doxográfias e comentários. Tradução de José Cavalcante de Souza et al. São Paulo: Nova Cultural, 2005.

VELTEN, Paulo. A humanização do Direito e a horizontalização da Justiça: O modus operandi ditatorial e a necessidade de revisão do conceito de segurança nacional. CONSELHO NACIONAL DE PESQUISA E PÓS GRADUAÇÃO EM DIREITO (CONPEDI), 18., 2014, João Pessoa. Anais do XXIII CONPEDI. João Pessoa: UFPB, 2014. p. 227-240.

Disponível: em:

$<\underline{\text { http://www.publicadireito.com.br/publicacao/ufpb/>. }}$.

Acesso em: 16 de março de 2017.

Trabalho enviado em 28 de janeiro de 2019

Aceito em 06 de fevereiro de 2020 